\title{
PANDANGAN ALKITAB MENGENAI PERNIKAHAN YANG TIDAK SEIMAN
}

\author{
Victoria Woen \\ Sekolah Tinggi Teologi Exelsius \\ vwoen@yahoo.com
}

\begin{abstract}
General theory: Marriage is an institution authorized by God which involves the union of a man and a woman as "one flesh" in a lifelong relationship. The method used by the authors in this study is a quantitative research method. In this research besides being descriptive, the writer also uses survey method because the survey method is one of the characteristics of descriptive research. The purpose of writing this article is to know the meaning of marriage in the Bible, the Old Testament view of unbelieving marriage, and the New Testament view of unbelieving marriage. The results obtained are, (1) the meaning of marriage in the Bible is an institution authorized by God which involves the union of a man and a woman as "one flesh" in a lifetime relationship. (2) The Old Testament view of unfaithful marriage, as exemplified by the biblical figures in the Old Testament, is known that the Israelites were not accustomed to marrying people from non-nationals or relatives. (3) The New Testament view of unbelieving marriage. II Corinthians 6:14 says: "Do not be an unequal partner with unbelievers." that marrying a partner who is not a believer or having a different religion is strongly opposed by the Bible. God does not want Christians to marry unbelievers because that will require a life-long struggle.
\end{abstract}

Keywords: marriage, faith, pastoral

\begin{abstract}
Abstrak
Teori umum: Pernikahan adalah lembaga yang disahkan Allah yang melibatkan penyatuan seorang lakilaki dan seorang perempuan sebagai "satu daging" dalam suatu hubungan seumur hidup. Metode yang dipakai oleh penulis dalam penelitian ini adalah metode penelitian kuantitatif. Di dalam penelitian ini selain bersifat deskriptif, penulis juga menggunakan metode survei karena metode survei merupakan salah satu ciri penelitian yang bersifat deskriptif. Tujuan Penulisan Artikel ini adalah mengetahui makna pernikahan dalam Alkitab, Pandangan Perjanjian Lama mengenai pernikahan tidak seiman, dan Pandangan Perjanjian Baru mengenai pernikahan tidak seiman. Hasil yang diperoleh yaitu, (1) makna pernikahan dalam Alkitab adalah lembaga yang disahkan Allah yang melibatkan penyatuan seorang laki-laki dan seorang perempuan sebagai "satu daging" dalam suatu hubungan seumur hidup. (2) Pandangan Perjanjian Lama mengenai pernikahan tidak seiman, sebagaimana teladan tokoh-tokoh alkitab dalam Perjanjian Lama, diketahui bahwa bangsa Israel tidak biasa menikah dengan orang dari bukan sebangsa atau sanak-saudaranya. (3) Pandangan Perjanjian Baru mengenai pernikahan tidak seiman. II Korintus 6:14 mengatakan: "Janganlah kamu merupakan pasangan yang tidak seimbang dengan orang-orang yang tak percaya". bahwa menikah dengan pasangan yang tidak seiman atau berbeda agama sangatlah ditentang oleh Alkitab. Allah tidak menginginkan umat Kristen menikah dengan pasangan yang tidak seiman karena hal itu akan membutuhkan pergumulan seumur hidup.
\end{abstract}

Kata Kunci: pernikahan, iman, pastoral 


\section{PENDAHULUAN}

Pada saat Adam pertama kali melihat Hawa, ia langsung berseru, "Inilah dia, tulang dari tulangku dan daging dari dagingku. Sehingga dinamai 'perempuan', sebab ia diambil dari laki-laki”" (Kejadian 2:23). Lebih daripada itu pula ternyata rancangan Allah juga dapat ditemukan di dalam ayat berikutnya: "Sebab itu seorang laki-laki akan meninggalkan ayahnya dan ibunya dan bersatu dengan istrinya, sehingga keduanya menjadi satu daging" (Kejadian 2:24). Jadi dalam hal ini dapat dikatakan bahwa pernikahan itu adalah suatu gagasan atau ide dari Allah sendiri bagi manusia dan hal tersebut telah ditentukan oleh Allah agar manusia itu baik laki-laki maupun perempuan untuk menjadi satu daging.

Di dalam kehidupan manusia jaman sekarang pernikahan bukanlah sesuatu yang dianggap suci atau sakral apalagi ada yang tidak berdasarkan pada Firman Tuhan. Jika di dalam Alkitab pernikahan adalah gagasan dari Allah sendiri maka sekarang bisa menurut kemauan diri sendiri. Termasuk proses sebelum pernikahan itu ada campur tangan dari Allah. Allah yang merencanakan dan meneguhkan pernikahan itu sendiri, tetapi manusia jaman sekarang tidak terlalu menganggap penting arti tersebut. Sehingga dalam mencari pasangan hidup pun seharusnya mencari kehendak Tuhan dan mencari pasangan hidup yang sungguhsungguh berkenan dihadapan Tuhan.

Manusia jaman sekarang lebih mengikuti kemauan diri mereka sendiri dalam mencari pasangan hidup. Jika Alkitab mengatakan untuk tidak menikah dengan yang tidak seiman, namun dalam perjalanan hidup jemaat juga masih ada yang menikah dengan pasangan yang tidak seiman. Lalu apakah bisa mereka hidup dengan pasangan yang tidak seiman, bagaimana mungkin yang terang bersatu dengan yang gelap? Lalu bagaimanakah hidup mereka setelah menikah? Lalu bagaimana penggembalaan gereja terhadap jemaatnya yang telah menikah tidak seiman? Artikel ini ditulis untuk mencari jawaban atas permasalahan tersebut di atas, dengan mencari pandangan yang benar dalam mencari pasangan hidup yang sungguh-sungguh berkenan di hadapan Tuhan serta bagaimana Alkitab menanggapinya. Karena pernikahan yang tidak seiman akan membutuhkan pergumulan seumur hidup mereka dan membutuhkan banyak perjuangan untuk memenangkan jiwa salah satu pasangan yang tidak seiman.

Tujuan Penulisan Artikel ini adalah menjawab pertanyaan-pertanyaan berikut: (1) Apakah makna pernikahan dalam Alkitab? (2) Bagaimanakah pandangan Perjanjian Lama mengenai pernikahan tidak seiman? (3) Bagaimanakah pandangan Perjanjian Baru mengenai pernikahan tidak seiman?

\section{METODE PENELITIAN}

Penelitian mengenai Pandangan Alkitab Mengenai Pernikahan yang Tidak Seiman menggunakan metode pendekatan Deskriptif Kualitatif. Penelitian deskriptif yaitu mengumpulkan data berdasarkan faktor- faktor yang menjadi pendukung terhadap objek penelitian, kemudian menganalisa faktor- faktor tersebut untuk dicari peranannya. ${ }^{1}$ Penelitian kualitatif merupakan penelitian yang berhubungan dengan ide, persepsi, pendapat, kepercayaan orang yang akan diteliti dan kesemuanya tidak dapat di ukur dengan angka. Dalam penelitian ini, teori yang digunakan dalam penelitian tidak dipaksakan untuk memperoleh

${ }^{1}$ Arikunto, Suharsimi. Prosedur Penelitian : Suatu Pendekatan Praktik. (Jakarta: Rineka Cipta, 2010) 151. 
gambaran seutuhnya mengenai suatu hal menurut pandangan manusia yang telah diteliti. ${ }^{2}$ Metode pendekatan Deskriptif Kualitatif adalah metode pengolahan data dengan cara menganalisa factorfaktor yang berkaitan dengan objek penelitian dengan penyajian data secara lebih mendalam terhadap objek penelitian. Informan dalam penelitian ini menggunakan teknik purposive sampling, yaitu teknik penentuan informan berdasarkan criteria atau pertimbangan tertentu.

\section{PEMBAHASAN}

\section{Makna Pernikahan dalam Alkitab}

Sejak awal dalam sejarah manusia, Allah telah menetapkan pernikahan sebagai suatu hubungan yang tidak terpisahkan, karena terbentuk dari penyatuan dua orang yang terpisah yaitu seorang laki-laki dan seorang perempuan sehingga menjadi "satu daging".

Ide pernikahan memang pada dasarnya adalah gagasan dari Allah untuk manusia, baik laki-laki maupun wanita. Termasuk juga di dalam proses menuju pernikahan itu pun pasti ada campur tangan Allah yang mengarahkan sehingga pernikahan itu dapat berjalan dengan lancar dan baik. Selain itu juga, pernikahan yang sudah direncanakan oleh Allah pasti akan selalu dituntun oleh Allah sendiri dalam setiap hal yang terjadi dalam pernikahan itu. "Satu daging" berarti bukanlah sekadar "menempelkan" dua orang menjadi satu, melainkan lebih merupakan peleburan" dua unsur yang berbeda menjadi satu. ${ }^{3}$

Lalu Yesus menjawab: "Apa yang telah dipersatukan Allah, tidak boleh diceraikan manusia" (Mrk. 10:5-9). Karena pernikahan bukanlah berasal dari manusia tetapi dari Allah, dan Allah-lah yang melembagakan pernikahan, oleh karena itu

${ }^{2}$ Basuki, Sulistyo. Metode Penelitian. (Jakarta: Wedatama Widya Sastra, 2006) 24. hanya Ia saja yang berhak untuk menentukan standarnya dan menetapkan aturannya.

Banyak kisah pernikahan tokoh alkitab Perjanjian Lama dalam yang dapat memberi gambaran kepada orang Kristen, bagaimana pandangan Allah Israel yang melarang pernikahan umat-Nya dengan orang dari luar bangsa mereka, misalnya Kej.24:4 mengenai istri Ishak, Kel. 6:23 Harun dan Eliseba anak Aminadab, dan juga kisah istimewa lain seperti Hak.14:3 tentang Simson dan gadis Filistin, disitu orang tua Simson bertanya "Tidak adakah di antara anak-anak perempuan sanak saudaramu atau di antara seluruh bangsa kita seorang perempuan, sehingga engkau pergi mengambil isteri dari orang Filistin, orangorang yang tidak bersunat itu?" 1 Sam.18:18 tentang Daud yang berkata pada Saul "Siapakah aku dan siapakah sanak saudaraku, kaum ayahku, di antara orang Israel, sehingga aku menjadi menantu raja?" yang mengindikasikan bahwa bangsa Israel tidak biasa menikah dengan orang dari bukan sebangsa atau sanak-saudaranya.

Oleh karena itu aturan yang sudah ditetapkan oleh Allah seharusnya tidak boleh dilarang oleh manusia. Karena pernikahan bukanlah berasal dari manusia tetapi dari Allah. Sehingga apapun yang dilakukan oleh manusia termasuk mengambil keputusan untuk menikah dengan seseorang harus menurut standar dan aturan yang telah ditetapkan oleh Allah.

Umat-Nya harus mengikuti pola ini. Karena segala sesuatu yang dilakukan harus menurut standar dan aturan dari Dia, yaitu sesuai dengan Firman Tuhan. Jika umat Kristen tidak mau dan lebih memilih caranya sendiri sebagai manusia, tentunya segala konsekuensi tetap dipertanggungjawabkan

${ }^{3}$ Munroe Myles, The Purpose And Power Of Love \& Marriage (Jakarta: Immanuel, 2006), 13. 
kepada Allah pada akhirnya. Hal inilah yang harus juga dipahami bahwa ketika pasangan menikah bukan hanya kata "cinta" saja, tetapi pernikahan itu ada standar dan aturannya karena memang pernikahan itu bukanlah gagasan atau ide manusia, bukanlah berasal dari manusia tetapi semua itu berasal dari Allah.

Di dalam Alkitab pun dengan jelas mengatakan bahwa pernikahan adalah lembaga yang disahkan Allah yang melibatkan penyatuan seorang laki-laki dan seorang perempuan sebagai "satu daging" dalam suatu hubungan seumur hidup. Pada dasarnya lembaga ini akan berlangsung selama kehidupan manusia di muka bumi. Namun, dalam kehidupan yang akan datang pernikahan tidak akan lagi. Karena Allah menginginkan hubungan manusia sebagai suami-istri harus seumur hidup artinya sampai mereka meninggal. Hal ini tentunya dituntut suatu kesetiaan dalam pernikahan. Sehingga hanya "maut saja yang dapat memisahkan". Arti "satu daging" tentunya bukan hanya menjadi satu secara jasmani, tetapi juga rohani, dan kesatuan dalam setiap aspek dalam pernikahan.

Pernikahan adalah fondasi karena di atas hubungan inilah Allah mulai membangun masyarakat. Sehingga masyarakat dengan segala bentuknya bergantung pada pernikahan demi kelangsungan hidup mereka. Pernikahan juga merupakan fondasi bagi gereja, komunitas orang percaya dan umat Allah.

Dalam agama Kristen pernikahan itu ialah ikatan lahir batin antara seorang lakilaki dan perempuan, sebagai suami istri yang didasari akan pengiringan kepada Kristus, pernikahan yang berpusat pada Yesus Kristus adalah Tuhan atas pernikahan itu. ${ }^{4}$

\footnotetext{
${ }^{4}$ Howard Gering, Kamus Alkitab (Jakarta: Persekutuan Injil Indonesia, 1990), 67.
}

Di dalam Perjanjian Baru pun menggambarkan hubungan antara Kristus dan Gereja-Nya sebagai hubungan pengantin pria dan pengantin perempuan. Hal ini merupakan analogi yang sangat penting dan implikasi yang penting untuk memahami bagaimana laki-laki dan perempuan harus berhubungan. Jadi, pernikahan memang seharusnya mencerminkan Kristus dalam kehidupan pernikahan umat Allah sehingga cerminan itu dapat terlihat juga dalam kehidupan bermasyarakat. Selain itu pernikahan yang sehat merupakan dasar gereja dan masyarakat yang sehat pula. Adalah tidak mungkin suatu gereja dapat dikatakan sehat, jika kehidupan pernikahan jemaatnya tidak sehat pula. Pernikahan yang sehat tentunya dibangun dan berjalan sesuai dengan Kristus dan hubungan ini harus didasarkan pada Kristus yang sebagai kepala dalam keluarga dan gereja.

Kehidupan dalam pernikahan yang berkenan di hadapan Allah tentunya harus sesuai aturan Allah, yaitu menurut Firman Tuhan. Menurut Paulus dalam II Korintus 6:14 mengatakan: "Janganlah kamu merupakan pasangan yang tidak seimbang dengan orang-orang yang tak percaya". Sebab persamaan apakah yang terdapat antara kebenaran dan kedurhakaan? Atau bagaimanakah terang dapat bersatu dengan gelap?". Jika dilihat tema pokok dalam 2 Korintus adalah dipertahankannya keutuhan pelayanan kerasulan Paulus, keaslian Injil yang dikotbahkannya dan implikasi Injil terhadap kehidupan orang Kristen. ${ }^{5}$

Dalam bahasa Yunani untuk "menjadi pasangan yang tidak seimbang" hanya didapatkan dalam Perjanjian Baru. Dalam Perjanjian Lama bahasa Yunani, perkataan ini digunakan untuk melarang pengawinan ternak

${ }^{5}$ Manfred T. Brauch, Ucapan Paulus Yang Susah (Malang: SAAT, 1997), 186. 
dengan jenis ternak yang berbeda (Imamat 19:19). Namun Paulus mengatakan hal itu baik dalam Imamat 19:19 maupun Ulangan 22:9-10 hanya sebagai kiasan saja. Hal tersebut menurut Manfred dalam bukunya dikatakan bahwa teks Im. 19:19 dan Ul. 22:910, merupakan larangan berbagai kombinasi yang tidak seimbang, seperti menabur benih yang berbeda pada tanah yang sama dan pakaian yang dibuat dari bahan yang berbeda. Dalam artian bahwa kiasan "menjadi pasangan yang tidak seimbang" berbicara tentang ketidaksesuaian, seperti ungkapan umum, "minyak dan air tidak mungkin bercampur."

Tafsiran menurut Wesley, dalam ayat ini Paulus menggunakan ilustrasi dari Ulangan 22:10 yaitu janganlah membajak dengan lembu dan keledai bersama-sama. Prinsip ini diambil oleh Paulus untuk menekankan bahwa tidak boleh dan sungguh bertentangan bila orang beriman merupakan pasangan yang tidak seimbang (menikah) dengan orang yang tidak beriman kepada Yesus Kristus. Tentang golongan orangorang yang beriman maupun yang tidak beriman, menurut Perjanjian Baru digolongkan menjadi dua golongan manusia, yaitu: orang yang beriman kepada Kristus dan orang yang tidak beriman kepada Kristus. Kedua golongan itu bertentangan satu sama lain (lihat I Korintus 5:10-11).

Menurut Pdt. Dr. Stephen Tong, pernikahan Kristen dan non-Kristen mempunyai perbedaan nilai kualitatif, yaitu: pernikahan Kristen didasarkan atas Allah sebagai sumber cinta sehingga orang Kristen hidup dalam cinta seperti Allah. Orang Kristen menjalankan sesuatu dengan teladan Kristus, meskipun dalam hal mengatakan "cinta" pada orang lain. Sedangkan orang non-Kristen mencintai sesuatu pasti ada sebabnya. Sebab itu terletak bukan pada luar diri yang lebih besar, tetapi di luar diri yang lebih kecil. Orang non-Kristen menyukai sesuatu karena menarik baginya. Jadi, obyek menjadi sebab untuk mengasihi.

Masih menurut Pdt. Dr. Stephen Tong, ada perbedaan penting tentang sumber cinta orang Kristen dan non-Kristen. Cinta orang non-Kristen bersumber dua, karena ketika pria non-Kristen mencintai wanita justru dia sendirilah yang menjadi sumber cinta. Begitu pula dengan wanita non-Kristen, ketika mencintai pria wanita itu sendirilah yang menjadi sumber cinta. Namun, bagi orang Kristen tidak berarti demikian. Orang Kristen harus mengakui, "Saya bukan sumber cinta. Allah-lah sumber cinta. Maka Allah memberikan cinta dalam diriku untukmu. Dan Allah memberikan cinta kepadamu untukku." Sehingga dalam pernikahan itu ada campur tangan Tuhan. Bukan inisiatif sendiri saja.

Paul Gunadi memberikan salah satu pedoman dalam menemukan pasangan hidup, yaitu dalam berpacaran kedua belah pihak harus saling menolong untuk bertumbuh dan makin dekat dengan Tuhan. sebab prinsipnya adalah segala hal yang dilakukan haruslah memuliakan Tuhan. Jika dalam berpacaran justru sebaliknya yaitu tidak memuliakanNya, dan semakin jauh dari Tuhan, dapat dipastikan bahwa hubungan itu tidak diperkenan-Nya.

Dalam kenyataan hidup jaman yang semakin maju ini, prinsip-prinsip seperti halhal di atas sudah tidak terlalu penting. Padahal larangan untuk tidak menikah dengan bangsa yang tidak percaya Allah sudah ada pada jaman Perjanjian Lama, begitu pun menurut Paulus dalam II Korintus 6:14 tentang pasangan yang tidak seimbang. Tetapi dalam kehidupan orang Kristen sekarang masalah berbeda agama atau tidak seiman tidak menjadi masalah besar. Bukankah seharusnya sebagai anak Tuhan dan orang percaya harus 
menuruti Firman-Nya. Tetapi konsep sekarang sudah berbeda: "Asalkan saya cinta dan sedikit menemukan kecocokan secara pribadi meskipun tidak seiman, tetap melanjutkan ke jenjang pernikahan." Sehingga ia membutuhkan pergumulan seumur hidup untuk memenangkan pasangannya yang belum percaya. Oleh karena hal itulah, penulis ingin meneliti tentang pasangan yang menikah tidak seiman dan bagaimana perspektif Alkitab dalam menanggapinya.

\section{Pandangan Alkitab dari Perjanjian Lama mengenai Pernikahan Tidak Seiman}

Di dalam Kejadian 2:18 dikatakan "Tuhan Allah berfirman: Tidak baik kalau manusia itu seorang diri saja. Aku akan menjadikan seorang penolong baginya yang sepadan dengan dia." Adam membutuhkan penolong, sehingga ia dibuat tidur nyenyak dan Tuhan "mengoperasi" dia lagi. Inilah pengaliran darah yang pertama di dalam Alkitab.

Pengaliran darah untuk penebusan adalah setelah Adam dan hawa berdosa, dan seekor binatang disembelih untuk menjadi pakaian mereka. Tetapi pengaliran darah pertama di dalam diri manusia dilakukan oleh Allah sendiri, ketika Allah memecahkan daging sehingga darah keluar dari Adam. Di sini terdapat ajaran yang penting sekali, suatu symbol yang ketat, yaitu tanpa pengorbanan tidak ada orang yang bisa menjadi pemimpin. Kalau Adam tidak mau dilukai, ia tidak mungkin bisa menjadi kepala keluarga. Ia harus ditidurkan dan menerima operasi dari Allah. Sewaktu Kristus darah, baru gereja muncul. Gereja adalah mempelai wanita Kristus. Kristus mencintai gereja-Nya karena Ia telah mencurahkan darah untuk gereja-Nya.
Ini dilambangkan pada waktu Kristus mati untuk memungkin gereja bisa berdiri. Dan ini dilambangkan oleh Adam yang harus tidur, dilukai, berdarah, tulang rusuk diambil untuk menciptakan Hawa menjadi penolong.

Ketika Allah menciptakan Adam, Ia juga tahu apa yang dibutuhkannya yaitu seorang penolong. Seorang penolong yang diambil dari tulang rusuk Adam, yaitu saat Allah membuatnya tidur. Arti dari tulang rusuk adalah untuk melindungi, membimbing dan menjagai wanita. Salah satu gambaran yang paling indah di dalam dunia ialah ketika seorang pria melindungi, membimbing seorang wanita. Rencana Allah supaya manusia membentuk keluarga yang indah dan bahagia, yang boleh menjadi cermin di dalam dunia ini bagaimana kuasa dan cinta Allah kepada manusia. Oleh karena itulah wanita diciptakan Allah untuk menolong suaminya, bukan untuk menguasai, memimpin maupun memengaruhi secara negatif, tetapi menjadi penolongnya. ${ }^{6}$

Selain hal tersebut, seorang suami juga harus jelas berjalan di dalam kehendak Tuhan, sehingga dia berhak memimpin seluruh keluarga di dalam menjalankan kehendak Tuhan. Jadi dapat dikatakan bahwa ketika Allah merencanakan supaya manusia membentuk keluarga yang indah dan bahagia yang dapat menjadi cermin di dalam dunia, adalah masing-masing dari istri atau suami harus melakukan tugasnya seperti rencana Allah, yaitu seorang wanita harus menjadi penolong bagi suaminya dan seorang suami harus berjalan dalam kehendak Tuhan. Dalam hal ini tentunya membutuhkan kesatuan dalam iman percaya kepada Tuhan dan tidak mungkin jika tidak seiman dapat berjalan di dalam kehendak Tuhan. 
Orang Kristen sebenarnya telah dilahirkan kembali dan hidup di dalam Kristus sehingga mereka hidup secara rohani, sedangkan orang yang tidak percaya tidak demikian. Orang yang belum mempercayai Yesus Kristus sebagai Juruselamat pribadinya masih dalam keadaan mati secara rohani. ${ }^{7} \mathrm{Di}$ dalam bukunya, Joe Berry menjelaskan bahwa alasan utama Allah menentang pasangan yang tidak seiman adalah karena hal tersebut suatu penghinaan terang-terangan terhadap kekudusan-Nya. Allah terpisah dan mengasingkan diri-Nya dari segala hal yang berdosa dan jahat. Mereka yang menjadi milik-Nya harus berusaha keras menuruti kekudusan-Nya. Kepada orang Israel, Allah telah memerintahkan, "Jadilah kudus, sebab Aku ini kudus" (Im 11:45). ${ }^{8}$

Terkait dengan hal tersebut pernikahan harus dihormati. Maksudnya adalah pada waktu pernikahan itu terjadi, berarti pribadi dan pribadi itu bertemu dan berjanji bersatu, sehingga ketika mereka menikah dan memilih seseorang untuk menjadi pasangan hidup harus benar-benar memilih seperti kehendak Tuhan. Menikah dengan seseorang bukan seperti memilih benda-benda yang disenangi. Tetapi menikah adalah suatu kehormtan yang Tuhan berikan kepada manusia, di mana pribadi tertarik dengan pribadi, di mana kedua pribadi berjanji untuk hidup bersama selamalamanya di dalam dunia ini.

Setiap orang harus menghormati pernikahan karena pernikahan menjadi dasar keluarga dan memberikan pengaruh dan tanggung jawab yang paling panjang di dalam diri dan hidup manusia. Oleh karena itu, dalam memilih pasangan hidup pun harus bisa -bertanggung jawab di dalam hidup.

\section{Perjanjian Baru Mengenai Pernikahan Tidak Seiman}

Allah telah menciptakan pernikahan itu sejak penciptaan manusia Adam dan Hawa. Maka pernikahan adalah lembaga pertama yang ditetapkan dan dikehendaki oleh Tuhan Allah sendiri. Selain itu pernikahan merupakan suatu institusi yang sakral dan unik karena institusi penikahan adalah institusi yang dibentuk oleh Allah sendiri sejak awal penciptaan manusia. Pernikahan harus kembali menjalankan rencana kekal Allah sehingga pernikahan bisa mencapai maksud aslinya yaitu manusia harus kembali kepada Allah dan Firman-Nya untuk mengertinya. Tanpa kembali kepada Allah dan Firman-Nya, manusia hanya bisa berspekulasi tentang pengertian dan hakikat pernikahan menurut pikiran mereka dan fakta dunia yang sudah jatuh ke dalam dosa ini. ${ }^{9}$

Pada hakikatnya pernikahan dirancang Allah untuk kebaikan manusia itu sendiri. Manusia pada naturnya memang tidak dapat hidup sendiri, maka Allah memberikan seorang penolong agar bisa menjadi satu pasangan yang serasi, yang indah dan bahagia (Kejadian 2:18-25). Namun dosa telah merusak relasi pernikahan yang indah. Hanya kembali kepada Tuhan dan relasi antar anak Tuhan yang memungkinkan mengembalikan manusia kepada kebahagiaan seperti ini. Itulah alasan Tuhan menginginkan pernikahan itu adalah pernikahan antar anak Tuhan sendiri. Tidak mungkin anak Tuhan bisa membina institusi pernikahan yang baik dan bahagia sejati dengan anak kegelapan (2 Korintus 6:13-18).

\footnotetext{
${ }^{9}$ Sutjipto Subeno, Indahnya Pernikahan Kristen (Surabaya: Momentum, 2012), 22.
} 
Pernikahan sejati yang memberikan kemungkinan kebahagiaan sejati akan dimulai oleh dua anak Tuhan yang bertekad menjadikan Allah sebagai Tuhan atas hidup pernikahan mereka. Hal tersebut merupakan tuntutan yang keras dan serius serta rahasia dari pernikahan yang sedemikian indah yang dibukakan kepada setiap anak Tuhan yang mau taat. Paulus mengungkapkan bahwa pernikahan ini merupakan rahasia yang besar, karena pernikahan ini merupakan hakikat perwakilan. Manusia yang menikah mereprsentasikan pribadi yang jauh lebih dalam. Diungkapkan bahwa pria menjadi representasi Kristus dan wanita menjadi representasi jemaat.

Paulus juga mengungkapkan bahwa pernikahan Kristen bukanlah sekadar dua orang yang sedang jatuh cinta lalu dengan segala pikiran nafsu dan keinginan duniawi memasuki mahligai pernikahan. Bukan sekadar "saya cinta kamu, kamu cinta saya dan kita menikah." Pernikahan sejati melampaui sekadar cinta kasih dua orang manusia, tetapi di belakang itu ada makna yang jauh lebih dalam dan kekal. Dengan demikian hal tersebut merupakan prinsip yang langsung memberikan dampak sangat dalam dan luas yaitu dua orang yang menikah tidak bisa sembarangan menikah, karena pernikahan dan pengakuan mereka di depan altar merupakan suatu pernikahan dan pengakuan yang bersifat mewakili. Keberadaan dan kehadiran pasangan yang menikah merupakan keberadaan dan kehadiran perwakilan. Kehidupan pernikahan mereka merepresentasikan hubungan antara Kristus dan jemaat-Nya. Maka setiap pasangan dalam pernikahan Kristen haruslah selalu mempertimbangkan prinsip ini.

\footnotetext{
10"Kategori Pranikah Pernikahan," accessed November 20, 2012,
}

Selain itu Paul Gunadi juga memberikan masukan bagi anak-anak Tuhan jika memilih pasangan hidup haruslah sesama orang percaya dan dalam proses pemilihan pasangan yang berkenan di hadapan Tuhan tentunya harus memohon pimpinan dari Tuhan dan juga harus taat pada perintah Tuhan yaitu menikah dengan pasangan yang seiman. Seperti yang dikatakan dalam 1Korintus 7:39 dikatakan bahwa janda-janda yang sudah kehilangan suaminya bebas menikah dengan siapa saja asalkan sesama orang percaya. Hal ini terlihat jelas bahwa umat Kristen tidak boleh berpasangan dengan orang yang tidak seiman dengan dan secara status yaitu 2Korintus 5:17 disebutkan orang percaya adalah ciptaan yang baru, orang yang tidak dalam Tuhan Yesus bukanlah ciptaan yang baru di mataNya. ${ }^{10}$

Dalam 2 Korintus 6:14-15, Janganlah kamu merupakan pasangan yang tidak seimbang dengan orang-orang yang tak percaya. Sebab persamaan apakah terdapat antara kebenaran dan kedurhakaan? Atau bagaimanakah terang dapat bersatu dengan gelap? Persamaan apakah yang terdapat antara Kristus dan Belial? Apakah bagian bersama orang-orang percaya dengan orangorang tak percaya? Pesan dari ayat ini jelas, bahwa dalam memilih pasangan hidup, orang kristen harus memiliki pasangan yang satu iman.

Tafsiran lainnya tentang 2 Korintus 6:14-15 adalah Paulus menekankan perintah untuk para pembacanya tidak memiliki hubungan apapun dengan penyembah berhala atau agama penyembah berhala tetapi meminta untuk hidup suci atau kudus di dalam Tuhan. pernyataan untuk to not be yoked together with unbelievers mempunyai

http://www.telaga.org/kategori/pranikah_pernikahan? page $=2$. 
maksud tidak mengambil bagian menyembah berhala dengan para penyembah berhala atau orang yang tidak percaya pada Kristus. Orang yang beriman tidak dapat ikut mengambil bagian dalam menyembah ilah-ilah lain karena orang percaya adalah hidup orang percaya adalah tempat tinggalnya Allah dan Allah berkata Aku akan hidup dengan mereka dan berjalan diantara mereka karena seseorang tidak dapat berjalan bersamaan dengan Allah dan juga mengambil bagian dalam menyembah berhala, orang percaya harus memisahkan diri mereka dari ilah-ilah lain. ${ }^{11}$ Menurut Eddy dan Susie Wiriadinata, jika menikah dengan pasangan yang tidak seiman, banyak hal dalam menjalankan kehidupan ini yang menjadi tidak bebas. Misalnya saja; salah satu harus menjaga perasaan pasangan, dalam mendidik anak, banyak hal yang harus dikorbankan demi menjaga keharmonisan keluarga. Keyakinan akan kehidupan dibalik kematian pun tidak bebas untuk diungkapkan. Akibatnya bisa menjadi tertekan.

Namun sebaliknya, jika pasangan itu seiman, dasar hidup mereka dari firman Tuhan dapat diterapkan. Cara mereka mendidik anak, mengajarkan keyakinan iman, cinta Tuhan, pelayanan, berbakti, belajar, berdoa, kosa kata yang digunakan tidak mengalami pertentangan dan kekhawatiran akan menyinggung pasangannya. Melihat bahwa persoalan tentang pernikahan dengan pasangan yang tidak seiman belum terlalu dipahami oleh orang Kristen jaman sekarang dan masih ada juga yang menikah dengan pasangan yang tidak seiman. Menurut Ny. Chong Kwong Tek dalam bukunya mengatakan: "Kita patut menekankan pentingnya bagi orang Kristen untuk menikah

${ }^{11}$ G.J. Wenham et al., New Bible Commentary, (USA: Intervarsity Press, 1994), 1198. dengan seorang yang seiman. Tetapi jika pada akhirnya mereka toh menikah dengan orang bukan Kristen, kita tidak boleh mencap mereka sebagai orang yang tidak taat."

Menurut pembahasan tersebut sudah sangat jelas bahwa yang merencanakan dan membentuk pernikahan itu sendiri adalah Allah. Sebagai umat Tuhan umat Kristen harus taat kepada perintah-Nya yaitu salah satunya memilih pasangan hidup yang seiman.

\section{KESIMPULAN}

Makna pernikahan dalam Alkitab adalah lembaga yang disahkan Allah yang melibatkan penyatuan seorang laki-laki dan seorang perempuan sebagai "satu daging" dalam suatu hubungan seumur hidup. Allah tidak menginginkan umat Kristen menikah dengan pasangan yang tidak seiman karena hal itu akan membutuhkan pergumulan seumur hidup. Anak terang tidak dapat disatukan dengan anak gelap, karena hal itu tidak dapat disatukan. Sumber kasih yang ada pada anak terang bersumber pada kasih Kristus sendiri, sedangkan sumber kasih pada anak gelap kepada dirinya sendiri.

Pandangan Perjanjian Lama mengenai pernikahan tidak seiman, adalah bahwa menikah dengan orang yang bukan dari sebangsa atau sanak-saudaranya merupakan suatu hal yang sulit diterima dalam budaya masyarakat setempat. Pernikahan merupakan rencana Allah sendiri dalam hidup manusia. Oleh karena itu setiap orang percaya yang akan menikah, seharusnya tidak menganggap remeh arti dari pernikahan itu sendiri karena Allah sendiri yang memberkati pernikahan itu. Orang percaya seharusnya memohon pimpinan hikmat Tuhan dalam memilih pasangan hidup. 
Pandangan Perjanjian Baru mengenai pernikahan tidak seiman adalah bahwa menikah dengan pasangan yang tidak seiman atau berbeda agama sangatlah ditentang oleh Alkitab. Allah tidak menginginkan umat Kristen menikah dengan pasangan yang tidak seiman karena hal itu akan membutuhkan pergumulan seumur hidup. Takut akan Tuhan adalah kriteria utama dalam memilih pasangan.

\section{SARAN-SARAN}

Melalui artikel ini diharapkan anakanak pemuda Kristen lebih berhikmat dalam mencari pasangan hidup, karena pernikahan hanya untuk sekali seumur hidup dan hanya maut yang memisahkan. Sedangkan bagi para hamba Tuhan di gereja seharusnya memberikan pemahaman yang mendalam bagi pemuda yang masih berpacaran atau dalam bimbingan konseling pernikahan untuk sungguh-sungguh menekankan akan hal ini. Memilih pasangan yang seiman dan sesuai dengan Firman Tuhan akan jauh lebih baik dan tentunya harus lebih bergumul dalam mencari pasangan hidup, karena tujuan menikah sesuai dengan kebenaran Firman Tuhan adalah hanya untuk memuliakan Tuhan melalui pernikahan.

\section{DAFTAR PUSTAKA}

Arikunto, Suharsimi. Prosedur Penelitian : Suatu Pendekatan Praktik. Jakarta: Rineka Cipta, 2010.

Berry, Jo. Bila Kekasih Belum Percaya. Jakarta: Gunung Mulia, 1985.

Basuki, Sulistyo. Metode Penelitian. Jakarta: Wedatama Widya Sastra, 2006.

Brauch, Manfred T. Ucapan Paulus Yang Susah. Malang: SAAT, 1997.

Gering, Howard. Kamus Alkitab. Jakarta: Persekutuan Injil Indonesia, 1990.
Myles, Munroe. The Purpose And Power Of Love \& Marriage. Jakarta: Immanuel, 2006.

Nazir, Moh. Metode Penelitian. Jakarta: Ghalia, 1988.

Subeno, Sutjipto. Indahnya Pernikahan Kristen. Surabaya: Momentum, 2012.

Sugiyono. Metode Penelitian Administrasi. Bandung: Alfabeta, 2011.

Tong, Stephen. Hati Yang Terbakar,. Vol. 3. Surabaya: Momentum, 2007.

Wenham, G.J., J.A. Motyer, D.A. Carson, and R.T. Frame. New Bible Commentary. USA: Intervarsity Press, 1994.

"Kategori Pranikah Pernikahan." Accessed November 20, 2012. http://www.telaga.org/kategori/pr anikah_p ernikahan?page=2. 